\title{
Jordan bid to the Gulf Cooperation Council and Implications for the Expended GCC
}

\author{
Shabir Mohsin Hashmi ${ }^{1}$, Zhao Yongliang ${ }^{2}$, Zainab Alhayki ${ }^{3}$ \\ 1 *Professor and Director, Belt and Road Research Centre, School of Economics and Management, Yancheng \\ Institute of Technology, Yancheng, Jiangsu, China, \\ Postal Code: 224051, E-mail: hashmi@ycit.edu.cn \\ 2*Professor, Dean, School of Economics and Management, Yancheng Institute of Technology, Yancheng, China, \\ Postal Code: 224051. E-mail: everbrightz@163.com (Corresponding author) \\ 3*Zainab Alhayki, Assistant Professor, Finance Department, Alasala College, Kingdom of Saudi Arabia, Email: \\ zainab.alhayki@alasala.edu.sa
}

\begin{abstract}
In 2011, the Gulf Cooperation council (GCC) invited Jordan and Morocco to join the council. This research is geared to evaluate the potential benefits of joining the GCC for the case of Jordan. It is argued that Jordan's inclusion to the block would strengthen the economy of the member states, increase trade and investment opportunities and improve peace in the region. GCC Membership to Jordan might possibly support its economy and larger investment flows from the Gulf countries. On the flipside, Jordan accession carries several potential benefits to the GCC. Jordan's strength is linked with its close proximity to the GCC, cordial relationships with the US and the EU and free trade agreements with major economies. Moreover, Jordan inherits professional military. If Jordan is part of the GCC, it might consolidate the military power and augment security of the GCC. Since the Arab Spring, the peace of the Middle East remained volatile. Recent rift between Saudi Arabia and Qatar, war in Syria and Yemen further destabilized the security of the region. This has also undermined the future of the GCC. In these circumstances, the expansion of the GCC is realistic and Jordan case caries some merit.
\end{abstract}

Keywords: GCC, Jordan, Economic Integration, Peace and Security

JEL: E61, F36, F50, F53, F59

DOI: $10.7176 / \mathrm{EJBM} / 12-6-14$

Publication date: February $29^{\text {th }} 2020$

\section{Introduction}

The Gulf Cooperation Council (GCC) was founded in 1980.It is intergovernmental regional economic and political cartel of six Arab States of the Persian Gulf. Bahrain, Kuwait, Qatar, Oman, Saudi Arabia and United Arab Emirates are its member. The main objectives of the GCC are to promote the socio-economic conditions of region and safeguard the sovereignty of the member states. In 2011, Saudi Arabia put forwarded a proposal to transform the GCC into a Gulf Union with closer economic, political and military coordination. Apart from economic cooperation, the prime goal of the GCC is to contain the influence of Iran in the Middle East ${ }^{1}$.The expansion of the GCC has been on the card since log ago. But after the Arab Spring, there has been serious discussion regarding the future membership to Jordan, Morocco and Yemen. Jordan shown it's interested in joining the Gulf Cooperation from the foundation of the club and again it made a request in1996. On $10^{\text {th }}$ of May 2011, during its meeting in Riyadh, the Gulf Cooperation Council (GCC) invited Jordan and Morocco to join the council. The Kuwait Times reported that Jordan bid to the GCC is warmly welcomed by the Kingdom of Bahrain and Saudi Arabia, while, Kuwait and Qatar expressed their reservations. It is argued that the Jordan accession to the council will not only enhance trade and investment opportunities but it will also reinforce the historical ties between the Arab countries. Since 2000, Jordan's per capita GDP has more than doubled and GDP grew around 8 per cent per annum. During financial crisis, the growth rate of Jordan declined but it has registered a positive recovery in the recent years .According to the IMF forecasts, the economy of Jordan is likely to grow 3.2 in 2019 and above 3 per cent for the next coming five years. Over the years, unemployment has remained a major problem to the Jordanian economy. In 2018, unemployment rate in Jordan was 13 per cent which is expected to slide a bit to 11.5 per cent in 2019. The unemployment will edge downward as the economy picks up the momentum, nevertheless, the rate will remain in double digits for the next couple of years, the IMF asserts in its forecast for Jordan.

Over the past couple of years, Jordan has signed free trade agreements with a number of countries including the U.S and the European Union, Bahrain, Canada, Egypt, Malaysia, Morocco, Singapore, Syria, Tunisia and the UAE. GCC is one of the major trading partners of Jordan. During last decade, bilateral trade between the GCC and Jordan has increased immensely. Among the GCC, Saudi Arabia is the top trading partner to Jordan. Saudi Arabia which supplies crude oil to Jordan topped the list of exporters, followed by China and the United States. This study is designed to understand the current realties of Jordan and the GCC relations in the economic and political areas so

\footnotetext{
${ }^{1}$ Andrew Hammond (2012). "Analysis: Saudi Gulf union plan stumbles as wary leaders seek detail".Reuters
} 
as determine Jordan's candidature for the council. Rest of the study is further organized as follows: The next section presents the macro-economy of Jordan. The second section elucidates Jordan's total trade with world and the GCC. Section three covers mutual gains from the expansion of the council. Section four discusses the mutual gains to the GCC. Section five pinpoints the implication for expanded GCC. The section six concludes the study.

\section{Jordan total trade with world and the GCC}

Despite of its humble natural resources, Jordan has increased its foreign trade beyond the many competing countries. Jordan has the most open economy in the Arab world, joining more FTAs than any of its neighboring. It has bilateral free trade agreements with major economies, with substantial duty-free, import quotas and other benefits. Because of its trade links with leading economies and its access to the world's major markets such as America, Japan, China, Australia, Scandinavia and other EU countries, Jordan enjoys leverage over its neighboring countries. Jordan has become the member of the World Trade Organization (WTO) on December 17, 1999. Succession to the WTO has helped Jordan to enter into the world market and promote its trade and investment flows.

Jordan's international trade figures are shown in figure 1. As evident in the figure, Jordan's foreign trade continued to grow throughout the reporting period. In 2005, Jordan's international trade was limited to $\$ 14.72$ billion. Its exports amounted to $\$ 4.27$ billion, while imports were stood at $\$ 10.45$ billion during the same period. The total trade of the country has increased by $13 \%$ reaching $\$ 16.6$ billion in 2006 . Jordan's foreign trade further increased in 2007 , amounting to $\$ 19.23$ billion. Jordan's international trade touched its heights in 2008 when its foreign trade reached to $\$ 24.5$ billion mark. Its exports grew by $37 \%$ from $\$ 5.7$ billion in 2007 to $\$ 7.78$ billion in 2008.The imports have also increased by $24.5 \%$ from $\$ 13.53$ billion to $\$ 16.87$ billion during the same period. Jordan's foreign trade adversely impacted in 2009 and its exports and imports sharply contracted. Compared to 2008 , Jordan's exports decreased by $14.7 \%$, while imports have also shrinked by $16.6 \%$ in 2009 . Jordan's foreign trade has picked up again in 2010, the volume of total trade has increased from $\$ 20.7$ billion in 2009 to 22.28 billion in 2010. Its exports and imports rose by $5.8 \%$ and $8.5 \%$ respectively during the same period. (Figure 1 ). The statistical data issued by the Department of Statistics have indicated that the Jordan's foreign trade increased by $18.3 \%$ in January 2011 , compared with January 2010 . Total exports and re-exports have also increased by $18.3 \%$ and $18.6 \%$ respectively. The imports of the country have surged by $40.8 \%$ during the same period. According to the World Bank, in 2017, Jordan's total value of exports was \$ 7,469 million, while its imports stood at \$20,407 million.

Figure 1: Jordan total trade vouume-2005-2010(Value in \$ billions)

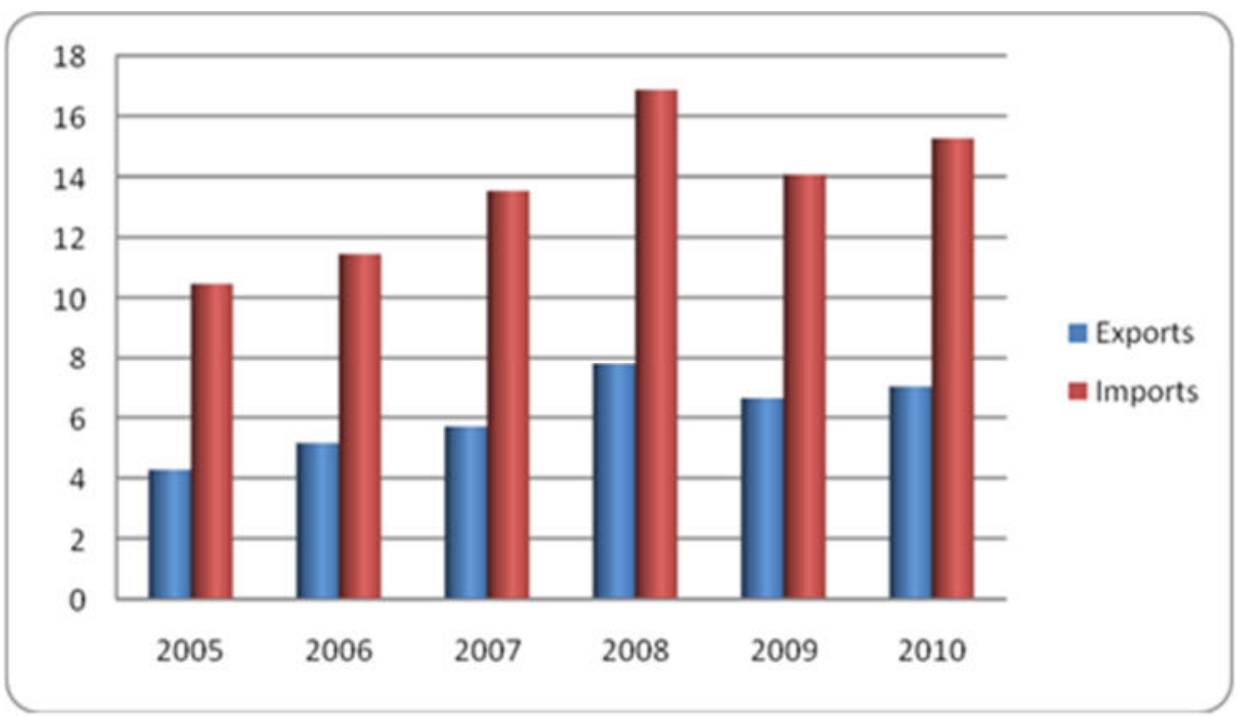

Source: UN Comtrade.

\section{1: Jordan's bilateral trade with the GCC}

GCC is one of the major trading partners of Jordan. During last couple of years, bilateral trade between the GCC and Jordan has increased noticeably. In 2017, the bilateral trade between Jordan and Gulf countries was estimated 
over $\$ 5$ billion. According to the Jordan Department of Statistics, in 2017, the GCC accounted for $24.2 \%$ of Jordan's imports, while $18.4 \%$ of its exports were destined for the Gulf States. Jordan imports from the GCC are mainly comprised of mineral fuels, oil, plastic articles, iron and steel and aluminum articles and thereof. On the other side, Jordan exports to the GCC are chiefly consists of edible vegetables, fruits and certain roots, pharmaceuticals, inorganic chemicals, precious metals, stones machinery, electrical and electronic equipments, and articles of iron and steel.

The flowing figure 2 shows the bilateral trade of Jordan with the GCC. As evident from the figure, among the GCC, Jordan has stronger trade links with the Kingdom of Saudi Arabia. Saudi Arabia which supplies crude oil to Jordan topped the list of exporters to Jordan.

Figure 2: Jordan's bilateral trade with the GCC-2010 (Value in \$ millions)

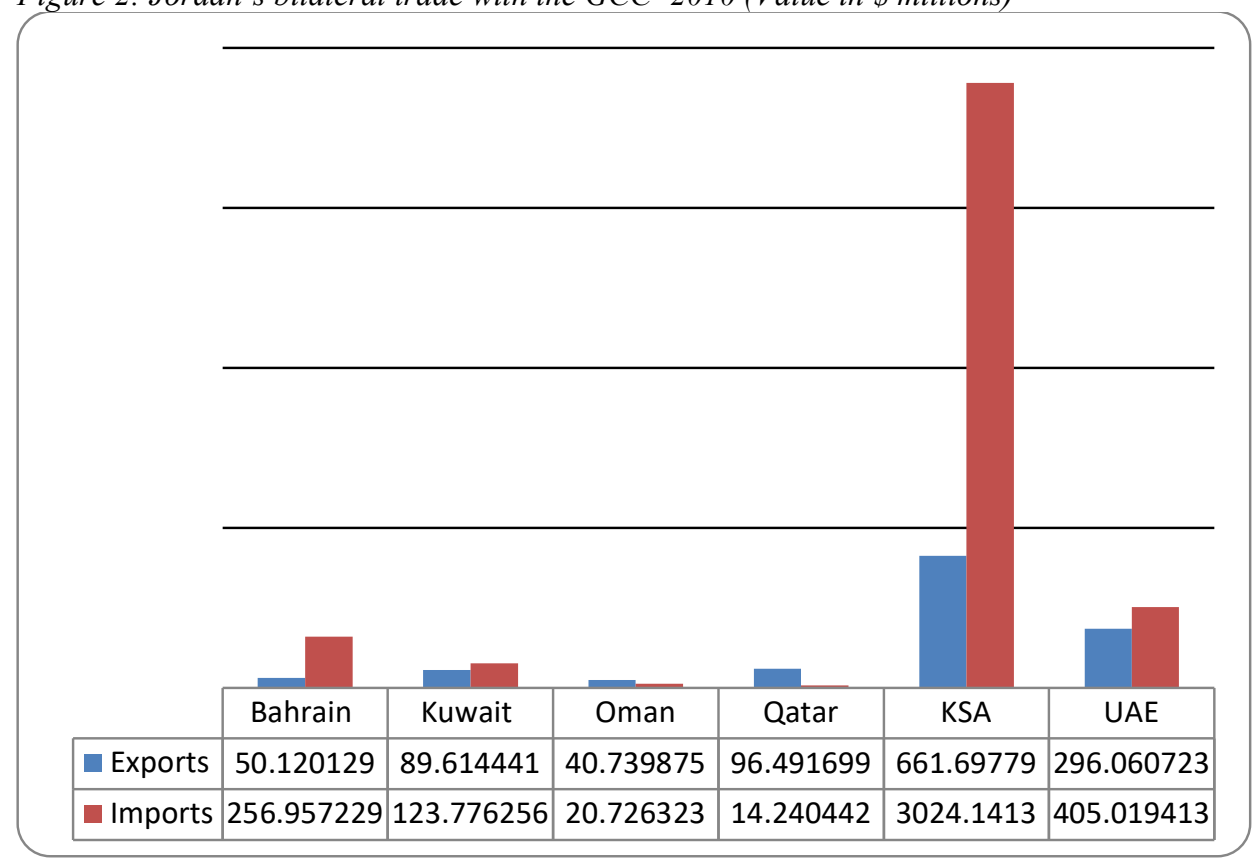

Source: Jordan Department of Statistics

In 2010, Jordan's trade (exports and imports) with Kingdom of Saudi Arabia surpassed \$ 3 billion, while total trade between the UAE and Jordan was reported over $\$ 700$ million. Jordan bilateral trade with Bahrain, Kuwait, Oman and Qatar was estimated at \$ 306 million, \$ 212 million, \$ 60 million and \$ 110 million respectively during the same period.

The breakdown of Jordan's exports by country of destination is shown in the figure 3 . It is revel from the figure that Iraq holds the top share in Jordan's domestic exports, followed by the U.S (13.4\%), India (10.4\%), Syria (7.4\%), Saudi Arabia (7\%), Lebanon (3.4\%) and the UAE (2.6\%). 
Figure 3: Jordan's Exports by country of destination, (2011-Q1)

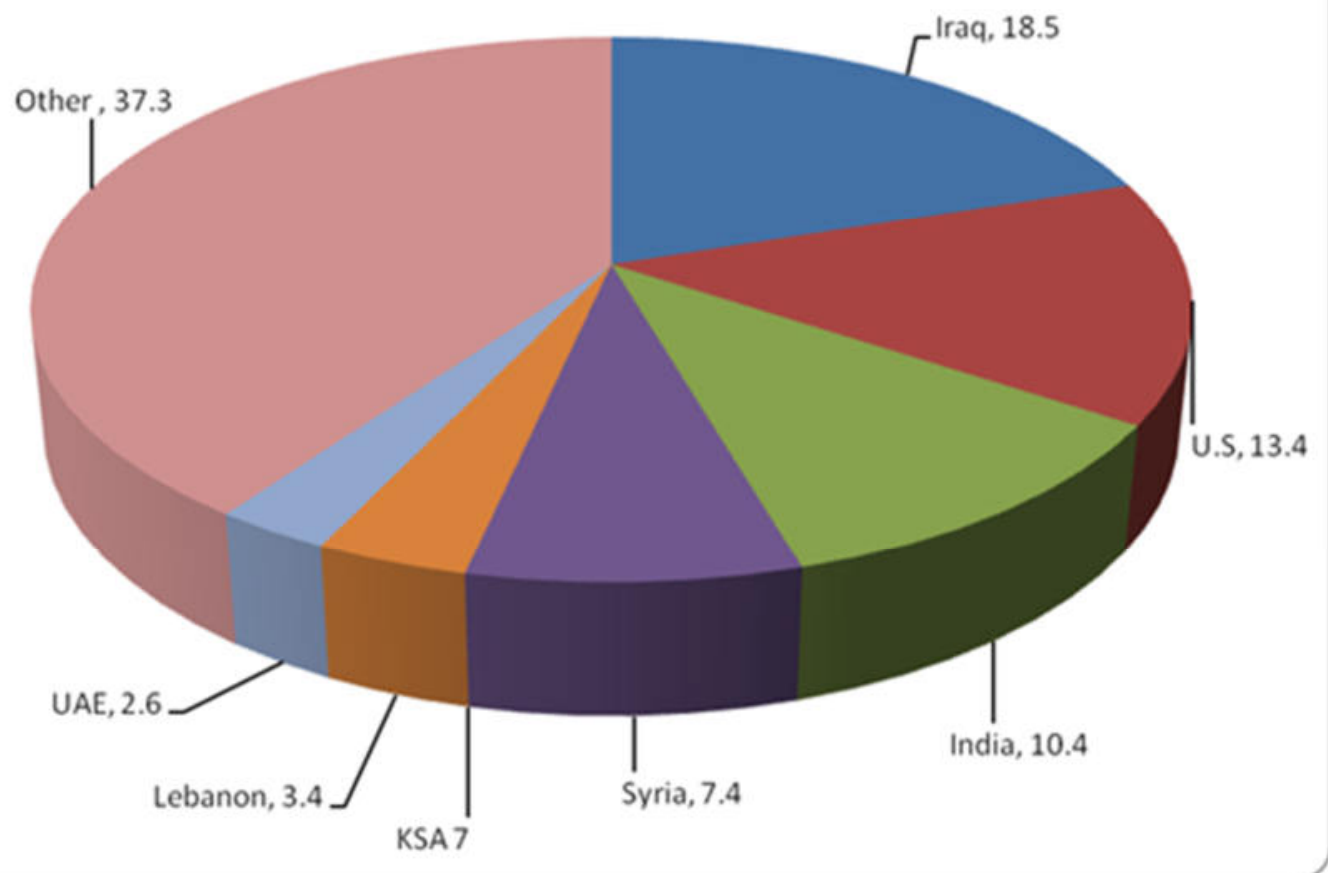

Source: Jordan Department of Statistics and the Central Bank of Jordan

The breakdown of Jordan's imports by country of destination is shown in the figure4.It is revel from the figure that Saudi Arabia is the top importer to Jordan followed by China (10\%), Germany (7\%), the U.S (5\%) South Korea (4\%) and others (53\%)

Figure 4: Jordan's Exports by country of destination(2011)

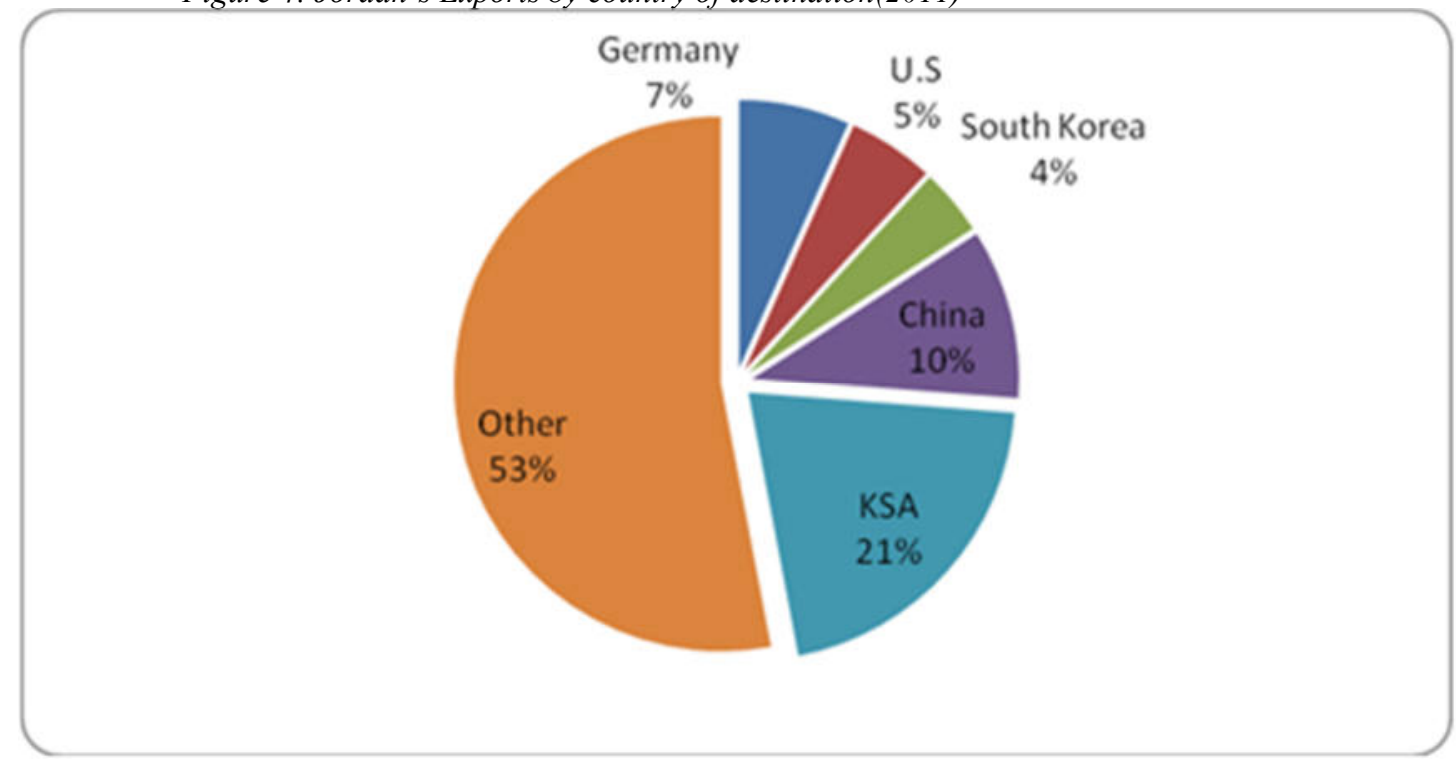

Source: Jordan Department of Statistics and the Central Bank of Jordan

The following figure 5 shows Jordan's major exporting commodities during the first quarter of 2011. As it is indicated in the figure, clothes and its related accessories stands top $(14.7 \%)$ in the exporting items followed by vegetables(14.3\%), crude potash(11.3\%), crudephosphate( $8.2 \%)$, fertilizers(7.9\%), pharmaceuticalsproducts $(6.3 \%)$ and others(37.3\%). 
Figure 5: Jordan's major Exports (2011)

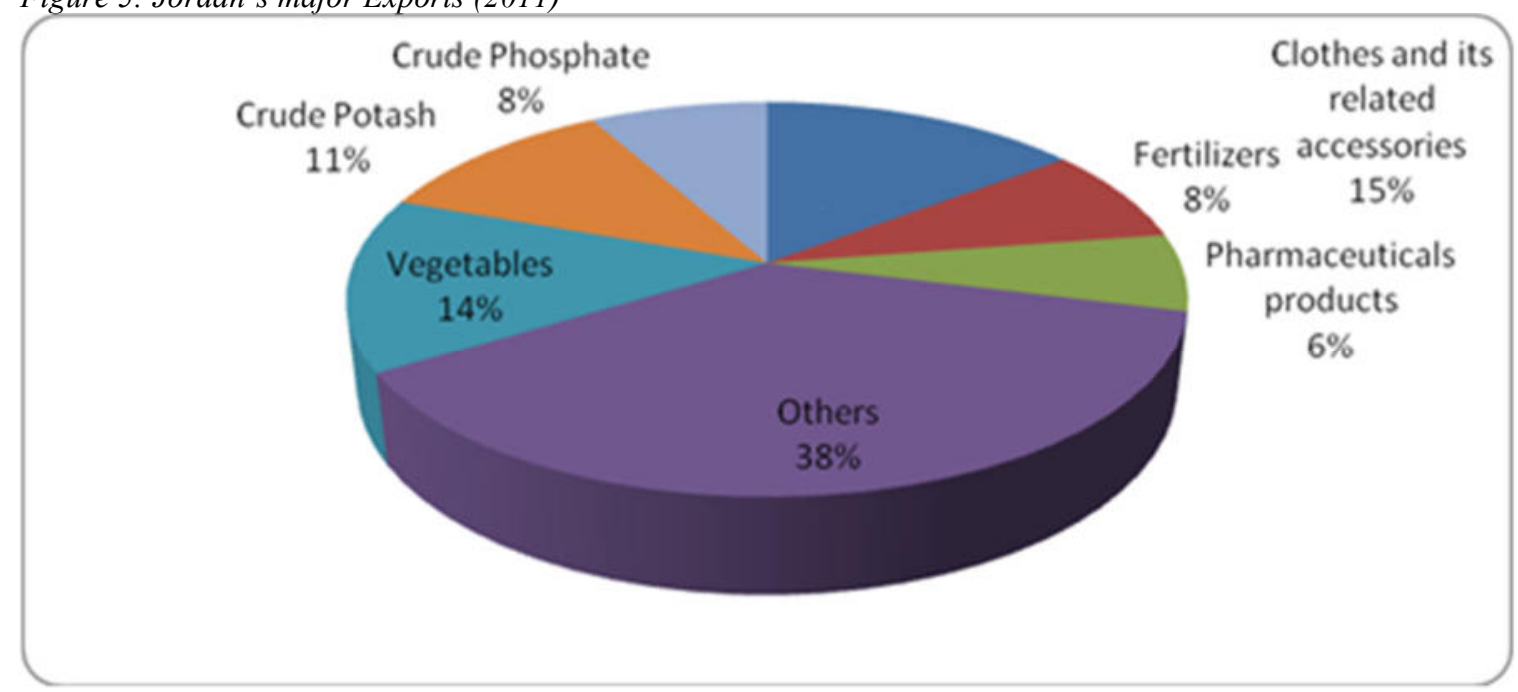

Source: Jordan Department of Statistics (DOS)

The following figure 6 show Jordan's major importing commodities during the first quarter of 2011.As it is indicated in the figure, crude oil is the single most biggest importing item(12.3\%)followed by machinery and its parts $(8.6 \%)$,machinery electrical appliances(4.8\%),vehicles, motorcycles and their parts( $7.5 \%)$, iron and its parts $(6.7 \%)$,plastic and its products(3.2\%)and others(56.9)

Figure 6: Jordan's major imports (2011)

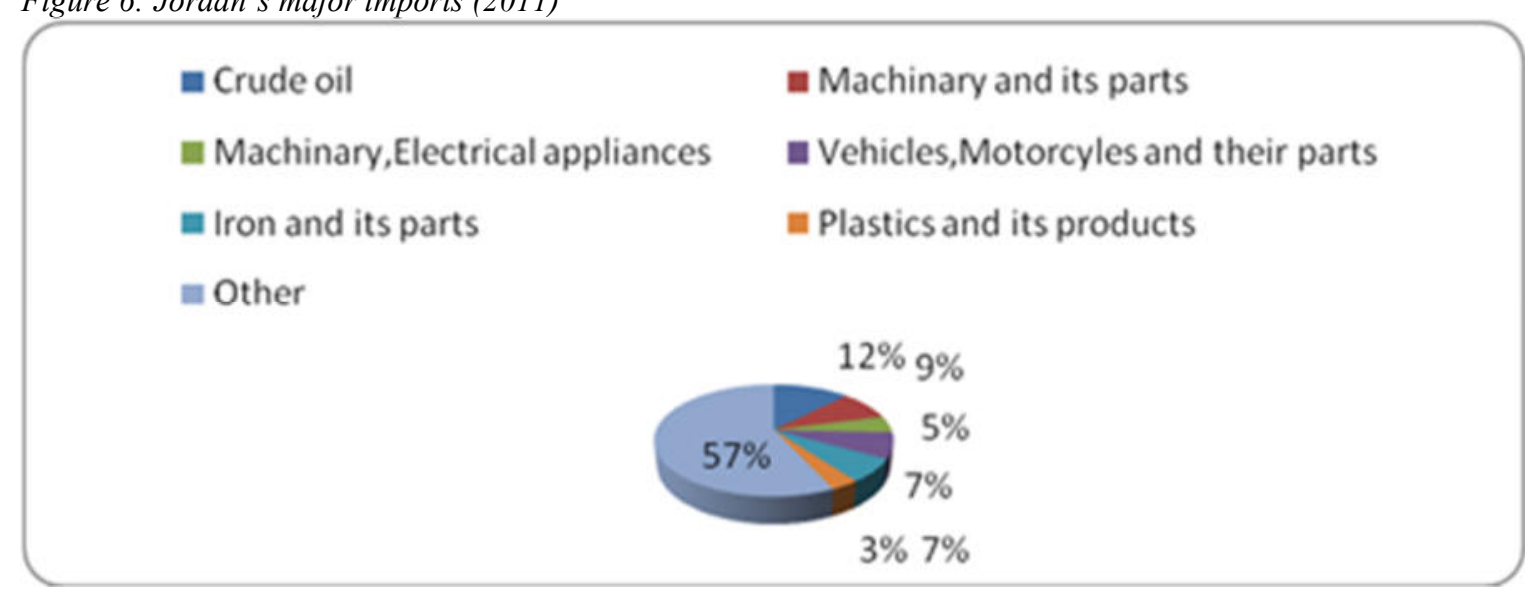

Source: Jordan Department of Statistics (DOS)

\section{Mutual gains from the expansion of the council: Gains to Jordan}

In comparison with the GCC, Jordan is a small economy with limited natural resources. Most of the experts believe that the GCC membership to Jordan will enhance the socioeconomic profile of the country. The accession to the GCC would enable Jordan to strengthen its economy, improve its trade deficit and boost foreign direct investment (FDI) from the rich six Gulf countries. On the economic fronts, Jordan is struggling with multiple challenges. Over the years, Jordan is the home of refugees; therefore, it heavily relies on foreign grants and aid to support the economy. In 2018, Jordan's budget deficit stood at $\$ 1.5$ billion or 5.4\% of the GDP, including foreign aid. The deficit is likely to remain high in the coming year. If Jordan is granted with the GCC membership, it would be eligible to apply for the monetary assistance from the GCC countries. Gulf Council provides monetary assistance to its members on the preferential basis. In 2011, when civil unrest broke out in Bahrain and Oman, the council has granted $\$ 10$ billion each of the two countries. The grant was meant to improve the economic condition of the member countries. GCC membership would give Jordan the similar access to the cash and other financial assistance. 
As Jordan's economy is growing, its energy needs especially demand for crude oil is surging with every passing year. For the energy needs, traditionally, Egypt and Iraq are the main oil suppliers to Jordan. But in recent years, Jordan's oil imports from the Gulf countries have also increased significantly. Figures from the UN Comtrade have indicated that in 2017, Jordan imported more than $\$ 2$ billion of oil and related products from the GCC. GCC membership to Jordan might help to get oil supplies from the GCC on subsidized rates.

Compared to the GCC, the agriculture sector of Jordan is large. According to the World Bank report 2018, approximately 20-25 percent of Jordanian active population is engaged in agriculture and food sector. Agriculture contributes 25-30 percent of the GDP when indirect contribution (the food sector) is considered. The report has further pointed that Jordan has recently witnessed an upward trend both in the value added of agriculture and its share to the GDP. Due to its large agriculture sector, Jordan is one of the main suppliers of food items to the Gulf countries. In 2017, Jordan has exported more than $\$ 180$ million worth of vegetables, fruits and meat to the GCC. Free access to the GCC markets will increase the demand for Jordanian goods which will untimely improve the trade deficit. Currently trade balance largely favors the Gulf countries. Jordan had over $\$ 2.6$ billion of trade deficit with the GCC in 2017.

Close ties with the GCC would enable Jordan to receive larger investment flows from block. In the past, Jordan received sizable amount of investment from Saudi Arabia, UAE and Kuwait, but the flows of investment have been arrested for the variety of reasons. In an endeavor to attract more investors, recently, the Jordan Investment Board (JIB) has announced more than 150 new investment projects which may re-generate the old links between the GCC and Jordan. According to the board, eleven cities of Jordan are looking for foreign partners to invest in their multiples projects. Investors will be granted special license in free zones and will be exempted from income tax and custom duties. There is a need to revitalize the flows of FDI between the GCC and Jordan. Jordan is one of the least developed countries among the Middle East. According to some estimates, large population of Jordanian lives below the poverty line. Poverty is very high among the refugees. If Jordan is granted the GCC membership, its GDP per capita will increase which will ultimately raise the living condition of the local people. Tourism plays an important role in Jordanian economy and it contributes approximately $12 \%$ to the GDP. If Jordan is become the member of the GCC, there will be a significant boost to its tourism industry. According to the data from the Jordan Ministry of Tourism, during 2017-2018, over one million visitors from the six GCC states entered Jordan. Tourists from Saudi Arabia alone accounted for $16.2 \%$ of total Jordanian visitors last year. Official figures indicated that the number of Gulf Arab tourists who visited Jordan last year made up $28.2 \%$ of the total number of visitors. The number of tourists will increase many folds if the GCC and Jordan follow visa free policy. Jordan has remained a major supplier of high caliber professionals to the Gulf countries. They not only contribute to the development of the GCC but also are the major source of remittance to their home country. Annually, Jordan receives sizeable amount of remittance from their expatriates and its share to the GDP is over 9\%. Free movement of labor force from Jordan to the GCC would not only help the GCC to acquire cheap labor force but it will also add considerable remittance to Jordan.

\section{Mutual gains to the GCC}

Jordan enjoys a very special location. It borders with Syria, Israel, Palestinian, Saudi Arabia, Iraq and Egypt. To this nexus, Jordan presents as an entry point for trade and investment with the Middle East and North Africa region (MENA).The location of the country allows for diversification and expansion into increasingly affluent markets .Over the last decade, Jordan successively concluded preferential trade agreements with major economies, including the U.S and the European Union.

Some analysts believe Jordan entry in the Gulf Council will unlock new trade and investment opportunities for the six oil rich nations. Compared to many developing countries, Jordan has good infrastructure, the country has instigated several investment incentives which offers very attractive return to the investors. According to the World Bank Ease of Doing Business Report 2018, taxes in Jordan as percentage of commercial profits are quite low. To the same report, Jordan needs less time for starting and closing of a business. Besides, the procedural requirement in Jordan are also much lesser than many countries.

Jordan has free trade agreements with the U.S and the European Union .Exports and imports originated from Jordan are exempted from the custom and other duties. In other worlds, trade and investment with Jordan means access to the U.S and the European markets. To this end, Jordan provides very special link to the GCC members to connect with the world's highly developed markets. 
GCC demand for heavy machinery and high tech products has been on the rise. If Jordan is become the member of the GCC, the gulf countries may be entitled to buy cheap and tax free heavy machinery and high tech products from the EU and the U.S all the way through Jordan.

According to the World Bank, the literacy rate in Jordan is $92 \%$, which is highest among the Arab countries. Jordan is the home of efficient and inexpensive labor force. The services of Jordanian professionals have been crucial for the development of the region. Jordan accession to the GCC means an addition some of ten million qualified professionals to the working force of the council.

Since couple of years, Jordan's pharmaceutical sector has emerged as the top exporting products of the country. In 2017, Jordan has exported over \$ 900 million worth of pharmaceutical products to the Gulf countries. Jordan can be the home of cheap and quality pharmaceuticals products if it is given the GCC membership.

\section{Implications for the expanded GCC (Six+ One)}

It is believed that the Jordan inclusion to the GCC would reinforce economic activities in the region, boost trade and investment opportunities among the member states. Moreover, new jobs will be created, exports might be diversified, education facilities will be enhanced, which will ultimately bolster the over image of the region.

\section{1: Strong Economic block}

According to some analysts, Jordan is the natural geographical extension to the Arab Peninsula. For the GCC countries, specifically for Saudi Arabia, Jordan is a natural fit. Saudi Arabia is the top trading partner to Jordan. While, Jordan exports to Kingdom of Saudi Arabia was \$ 844 million during 2017 according to the UN Comtarde database. Jordan and the GCC enjoys the same culture, same religion, same language and to some extent same real GDP growth rate, except, Qatar whose GDP growth rate remained higher since couple of year. The GDP growth of Jordan is in consistent with other members of the council. The inflation trends are also similar, though the consumer price pressure is higher in Jordan and Saudi Arabia then the other five countries.

Among the Arab countries, Egypt and Jordan own very professional military. Jordan has close links with United Sates and its army is trained by the US military therefore Jordanian military is considered highly skilled. If Jordan is given the GCC membership it would supplement the military strength of the GCC and might play a vital role in maintaining the law and order situation of the region. Recently, some of Arab countries have witnessed civil unrest and continuous demonstrations which has threatened the security future of region.

According to some estimates, Jordan will put in some $\$ 30$ billion annually to the GCC, if it its membership is accepted. In 2017, Jordan's GDP was over at \$ 40 billion, while combined GDP of the GCC was over \$1,250 billion. If we combine the GDP of Jordan and the GCC that will touch to \$ 1,279 billion mark. In other words, Jordan's inclusion will add approximately of $2.3 \%$ to the combined GDP of the GCC.

The members of the Gulf Cooperation Council are negotiating on the single monetary currency union. In future, if they reach to any conclusion, Jordan will be in line with their arrangements, as it is already pegged with the US dollar. It would be easy to adopt a joint single currency.

Jordan has very strong trade ties with the GCC. Last year in 2018, the bilateral trade between Jordan and the GCC countries was estimated over \$ 6 billion. According to the Jordan Department of Statistics, in 2017, the GCC accounted for $24.2 \%$ of Jordan's imports, while $18.4 \%$ of its exports were destined for the Gulf States.

\section{2: Limited advantage to GCC: Disadvantages outweigh the gains}

Usually, economic integrations uplift the socio-economic conditions of the united blocks. However, there are some policy makers who seriously oppose the idea. The critics believe that the Jordan accession to the GCC will add very little to the economic development of the council.

There are enormous economic difference between the GCC and Jordan. Gulf country's economy is mainly based on hydro carbon wealth, while Jordan hardy owns such reserves. The per capita income in the Gulf States is very high. According to the IMF data 2018, aside from Qatar, the average per capita income of the other five countries is $\$ 36,000$ per annum. Oman and Saudi Arabia have the lowest per capita income of around \$25,000 annually. Bahrain and the UAE have the annual per capita of $\$ 40,000$, while the per capita income of Kuwait stood at $\$ 52,000$ for the same period. In case of Jordan, the per capita income never exceeds $\$ 5,000$ per annum. Budget deficit and public debt are the biggest issues to the Jordanian economy. In 2018 Jordan's budget deficit stood at \$ 1 billion while its public debt to the GDP was over 94 percent. In contrast, half of the GCC members enjoy 
budget surplus. To this end, Jordan's union could hamper the economic progress of the GCC members. Unemployment and poverty are high in Jordan. Figures from World Bank have indicated that in 2018, unemployment rate in Jordan was $13 \%$. Since 2010, Jordan has not released poverty figures but according to some estimates, over $14 \%$ of the Jordanian lives below the poverty line. On the contrary, poverty and unemployment rate in the GCC is relatively low.

To some experts, Jordan inclusion will create lot of troubles to the GCC. Citing the example of the European Union, it is argued that after the establishment of the EU, the economic conditions of some of its members have further aggravated. Poor economic conditions of Spain, Romania, Portugal and Greece are partly blamed to the policies of the European Union.

Owing to the influx of foreign labor force, unemployment rate is gradually swelling in the GCC. In 2016, nonpayment of salaries crisis to foreign workers in Saudi Arabia sent a clear message to the foreign workers that the GCC is no more capable of accepting hordes of foreign worker. To address the issue and put a limit on the flows of foreign workers, recently Saudi Arabia, Qatar, Kuwait, UAE have outlined a new labor policy for the overseas employees. If Jordan is given the GCC membership, multitude of unemployed workers will enter into the GCC labor market, thus creating lot of pressure to the GCC labor market which is already reached to the saturation point.

\section{Conclusion}

It is assumed that in the long run, Jordan accession to the GCC will give boost to the economies of the member states and potentially supplement security of the region. However, there is need to re-estimate the cost and benefits of the move. There are large economic differences between Jordan and the GCC. Jordan economic conditions and infrastructure is weak. Its macroeconomic indicators- specially, public debt to the GDP, per capita income, savings and consumption are far behind the member states of the GCC. Correspondingly, on the economic development stages, the six oil rich countries enjoy the age of high mass consumption. Whereas, Jordan is still a developing country, hence, such variations in the economic structure of the blocks might pose serious challenges to the integration process.

It took fifty years to form the European Union. Recent economic crisis in the Southern and Eastern Europe, European sovereign debt crisis, have established the fact that the integration is not a panacea to all economic ills. Hence, before granting the GCC cap, it's vital to provide enough time to Jordan so it can develop its infrastructure and harness its economy in align with the GCC. Investment should be diverted to Jordan. It is the responsibility of the GCC to offer enough capital and the required resource to Jordan so it can catch up with development process.

During the formation process of the EU, some EU countries have been given financial assistance along with ten years' time frame work to develop their economies. The same formula may be applied in the case of Jordan. Expansion of the GCC is certainly much easier than the formation of the European Union as currently GCC is a block of only six countries and possibly-extend membership to couple of more countries in the near future. For the possible expansion of the GCC, a fund was established in 2011. The fund will provide financial assistance to the future member states and will assess the needs of the country and issue financial assistance accordingly. The fund will also offer soft loans to the aspiring countries. In 2018, the fund has sanctioned $\$ 2.5$ billion grant to Jordan.

Until Jordan gets full membership, for the time being, a free trade agreement might be signed between the GCC and Jordan. Jordan has free trade agreements with some of the council members. Hewer, for the upliftment of trade and investment cooperation such arrangements are necessary. As some experts believe Jordan extension to the GCC is a natural fit. Jordan accession to the council will not only enhance trade and investment opportunities but it will also reinforce the historical ties between the Arab countries.

\section{Compliance with Ethical Standards:}

It is certified that the paper is not concurrently being considered for publication elsewhere in any language and is not under consideration at another publication.

Funding: This study is funded by the Yancheng Institute of Technology

(Grant number Y8923J).

Conflict of Interest: we hereby declare that we have no conflict of interest. 
References:

Abdullah, D. A (2012).Repercussions of the Arab Spring on GCC States .Arab Research Centre and Policy Studies.

Ansani, A. \& Daniele, V((2012).About a revolution. The economic motivations of the Arab Spring”. International Journal of Development and Conflict, 3.

Asma Alsharif (2011) 1-Gulf bloc to consider Jordan, Morocco membership.Retrived from Reuters on 10 May 2011.

Ayubi, N. (2001). Overstating the Arab state: Politics and society in the Middle East. London: I.B. Tauris.

Asonuma, T., Debrun, X., \& Masson, P (2012). Welfare effects of monetary integration: The common monetary area and beyond. Washington DC: IMF Working Paper, No. WP/12/136.

Bley, J., Saad, M. (2010).Cross-cultural differences in seasonality. International Review of Financial Analysis (19) $306-312$

Bryant, Sara, “Dorothy Arzner's Talkies(2013).Gender, Technologies of Voice, and the Modernist Sensorium, Modern Fiction Studies 59- 346

Dar, H., \& Presley, J. (2001). The Gulf Co-operation Council: A slow path to integration. World Economy, 24, 1161-1178.

Darrat, A., \& Al Shamsi, F.(2005).On the path of integration in the Gulf region. Applied Economics, 37, $1005-62$.

El-Erian, M. A., \& Fischer, S. (1996). Is MENA a region? The scope for regional integration. IMF Working Paper 30. Washington, DC; International Monetary Fund.

El-Said, H. (1996). Jordan: the Political Economy of Industrialisation in A Rentier Economy, PhD thesis, University of Manchester.

GCC Members Consider Future of Union (2015).The Pulse of the Middle East". Al-Monitor. Retrieved 15 April

Matthews, R. (1986).The Economics of Institutions and Sources of Growth, Economic Journal, Vol. 96, 903-918.

Laleh Khalili, J. S. (2011). Revolution in the Arab World: The Long View. Washington: Center for Contemporary Arab Studies.

Meriggi, Marco, (2018).Global History: Structures, Strategies, Open Problems,Annals of the Fondazione Luigi Einaudi: An Interdisciplinary Journal of Economics, History and Political Science 52, 35-44

Sing, Manfred. (2017).Arab Self-Criticism after 1967 Revisited: The Normative Turn in Marxist Thought and Its Heuristic Fallacies," Arab Studies Journal 25, 144-90

Williamson, O. (1998).Transaction cost economics: How it works, where it is going, The Economist, Vol.146, 2358

Yousef, T. M. (2004). Development, growth and policy reform in the Middle East and North Africa since 1950. Journal of Economic Perspectives, 18, 91-116.

Zarrouk, J. (2003) A survey of barriers to trade and investment in Arab countries. In A. Galal, \& B. Hoekman (Eds.), Arab economic integration: Between hope and reality. Washington, DC: Brookings Institution Press. 